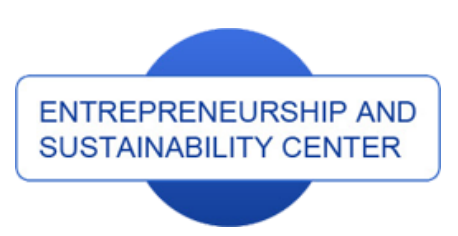

Publisher

http://jssidoi.org/esc/home

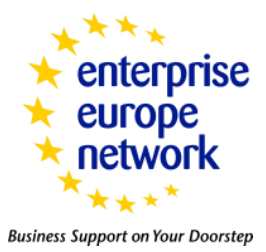

CASPA

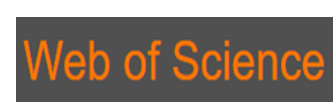

Clarivate
Analytics

\title{
AN OVERVIEW OF BUSINESS MODELS IN THE CZECH CHEMICAL INDUSTRY:A SUSTAINABLE MULTIPLE VALUE CREATION PERSPECTIVE*
}

\author{
Peter Kita ${ }^{1}$, Iveta Šimberová ${ }^{2}$ \\ 1,2 Brno University of Technology, Kolejní 2906/4 61200 Brno \\ E-mails. ${ }^{1}$ kitap@fbm.vutbr.cz ; ${ }^{2}$ simberova@fbm.vutbr.cz (corresponding author)
}

Received 15 March 2018; accepted 22 October 2018; published 30 December 2018

\begin{abstract}
The article presents results of empirical research conducted on companies in the Czech chemical industry, namely CZ NACE 20.1 manufacture of basic chemicals, fertilizers, and plastics. The main goal of the research was to describe novel business models based on sustainable multiple customer value creation. The article's objective is to present some of the findings from this research to provide an overview of utilized business model elements and characteristics of the industry within the scope of its business models. The original research design combines theoretical concepts of business models, sustainable value creation and multiple customer value to answer the later mentioned research questions. The article states the theoretical background of the research, research design and methods, results, and concludes by stating insights concerning the industry and the respective theory.
\end{abstract}

Keywords: sustainable value creation; business models; chemical industry; multiple value; research results; majority business models; minority business models

Reference to this paper should be made as follows: Kita, P.; Šimberová, I. 2018. An overview of business models in the Czech chemical industry: a sustainable multiple value creation perspective, Entrepreneurship and Sustainability Issues 6(2): 662-676. http://doi.org/10.9770/jesi.2018.6.2(14)

JEL Classifications: M21, Q01

\section{Introduction}

The scope of sustainability and novel value creation is connected to novel business model conception. These business models widen the very narrow focus on the economic aspect of value creation by integrating environmental, social aspects into them. Current knowledge in this area points at business model innovation as a means of gaining a competitive advantage through sustainable multiple customer value creation. This is underlined by the rise of novel competitive forces on the global market can disrupt the business models of companies that fail to adapt. In this regard, the chemical industry represents one of the largest industries in the

\footnotetext{
* This paper was supported by the research project: Use of the holistic concept in company management, which is founded by Specific Research of FBM BUT, grant number FP-J-18-4915
} 


\section{The International Journal}

ENTREPRENEURSHIP AND SUSTAINABILITY ISSUES

ISSN 2345-0282 (online) http://jssidoi.org/jesi/

2018 Volume 6 Number 2 (December)

http://doi.org/10.9770/jesi.2018.6.2(14)

Czech Republic. By nature the chemical industry has the ability to gauge its impact precisely and transform environmental and social challenges into sources for novel value creation opportunities. The article focuses on searching for novel approaches in business models of the Czech chemical industry which could promote a novel value proposition in the context of sustainability and social responsibility as a result of multiple customer value creation.

The paper's objective is to present some research results which provide some insights an overview of the utilized business models in the Czech chemical industry, specifically section 20.1 according to CZ NACE, in connection to novel business models based on sustainable multiple customer value creation. The aims of the underlying research are to provide a methodology to study an industry through the scope of its business models and utilize it on a specific industry to identify novel business models. Specifically, the research was conducted to identify the specific elements (or features) of novel business models based on sustainable multiple customer value creation within the context of the chosen industry.

The research design is based on the works of different authors. Based on these methodologies and research a questionnaire was developed to fit the specific goal. The questionnaire's relevance was tested during semistructured interviews with 9 industry representatives from various companies belonging in the sample. The sample consists of all 38 companies falling into section 20.1 CZ NACE. These representatives evaluated the relevance of suggested business model elements from a set based on literature retrievals. The result was a questionnaire consisting of 32 questions tied to the most relevant business model elements. The questionnaire was primarily targeted at commercial directors or production directors and the elements served as a foundation to provide an overview of the business models for the selected industry.

In a capital-intensive industry, such as the chemical industry, under the spotlight of many external audits and under heavy legislation, following the issued legislation becomes a competitive advantage. The majority (Slávik, 2014) and minority business model constructs state the business model elements utilized by most of companies and vice versa. In effect the legislation and constant audits pushes companies towards more industrial safety and meeting environmental customer expectation while social expectations are being met by a smaller number of companies.

\section{Theoretical background}

The theoretical foundation of the research is based on two theoretical bodies. First, sustainable multiple customer value creation and new business models. By incorporating the notion of sustainability and multiple value creation into a company's strategy it is forced to change the narrative of how it creates, delivers, and captures diverse types of value, i.e. the business model changes. The following part presents a literature review to frame sustainability, novel business models and multiple customer value creation.

\subsection{The scope of sustainability}

The scope of sustainability is not limited just to environmental issues, but also the sustainability of economic growth and social cohesion. According to the European commission, the flexibility of sustainability's principal is exercised through social responsibility. Corporate social responsibility represents a voluntary integration of social and ecological interests into corporate strategy and into day-to-day operations and relations with stakeholders (Livre Verte, 2003; Tvaroviciene, 2018). In the future, there is only going to be more customers, employees, board members, banks, suppliers etc. monitoring corporate operations (Záležaková, 2014). In other words, the company has to ensure that achieving economic efficiency is aligned with social and environmental protection standards (Chabi, 2016; Lankauskiene, Tvaroviciene 2012). Liikanen (2004) describes this form of governance as 


\section{The International Journal}

ENTREPRENEURSHIP AND SUSTAINABILITY ISSUES

ISSN 2345-0282 (online) http://jssidoi.org/jesi/

2018 Volume 6 Number 2 (December)

http://doi.org/10.9770/jesi.2018.6.2(14)

such increasing the positive contribution of the company to society and also minimizing the negative impact on citizens and their environment. The company is confronted by numerous challenges, whether economic, environmental, or social which include various influences and consequences for corporate operations. The compounding of these challenges can enact a chain reaction endangering the company's business model but also serve as incentives for novel business model design. The main priority for current company management is to create institutional and cultural conditions for business model development based on corporate flexibility and learning mechanisms. In this regard, Schaltegger et al. (2012) present the term sustainable business model innovation. Sustainable innovation is viewed as key to creating a sustainable company (Girotra, Netessine, 2013). It has a significant positive impact or significantly decrease the impact on the environment and society through the change of how the company and its value network create, deliver and capture value or by changing the value proposition (Bocken, Short, Rana, Evans, 2014). This ensures the company's competitiveness in the future and cause changes in the current business model. Radical and disruptive business model innovation changs the business model in its essence and provides a significantly greater value than that of the industry's standard. At the same time, these business models share this value among the company, its customers and value network partners, i.e. the ecosystem.

\subsection{Novel business models}

The issue of novel business models and multiple value creation is partially mentioned by numerous authors as are Boons, Lüdeke-Freund (2013); Schaltegger, Hansen, Lüdeke-Freund (2016), and others. The interest of academia and practitioners in the field of novel business models is ever-increasing. This is testified by the numerous definitions provided in scientific journals as Journal of Cleaner production, Long Range planning, Journal of business models, Organization and the Environment, etc. Several Czech authors also deal with this issue mainly in regard to business model innovation (Chwaszcz, 2010), sustainable development and corporate social responsibility (Kašparová, 2006; Prskavcová, Maršiková, Řehot’íková, Zbránková, 2008; Zadražilová et al., 2010, 2011; Pavlík, Bělčík et al., 2010; Kunz, 2012; Dalíková, 2013; Kocmanová, Šimberová, 2014), as well as other related issues (Švejda, 2002; Basl, 2002; Koráb, Mihalisko, 2005; Jakubíková, 2008; Pilný, 2016; etc.).

The notion of a novel business model (Bocken, Short, Rana, Evans, 2014) comprises three dimensions which individually possess a different meaning:

- "business" in the sense of entrepreneurship (Słavinska, 2010; Freeman, Wicks, Parmar, 2004) means economic activity of providing good and services which includes financial, commercial, and production aspects;

- "model" as a simplified representation of a process or system (Jensen, 2013). As with other terms in social sciences, models are not physical object. They possess an abstract character and are the result of modelling, i.e. the business model is societal construct. The term model relates to the notion of a company's unique nature, i.e. the competitive strength of a system is related to the ability to innovate. Innovation in this regard is the center point for strategic changes, i. e. designing and redesigning the business model with social responsibility incorporated into its value proposition. The term "business model" infers a graphical representation of the entrepreneurial process (Léon, 2014-15; Beattie, Smith, 2013). In its simplest form, the business model is a way of generating profit. This is due to fact that the business model is a basic entrepreneurial structure of which services are provided or which goods are produced in order to generate a profit (Muelhlhausen, 2018).

- the adjective "novel" is rooted in the support of a creative approach to strategy. The term is relates to searching for other solutions than the current model (Lehman-Ortega, Misikas, Schoettl, 2007). At the same time the term underlines that the novel business model is a significant non-technological innovation, although the model provides connection between technology and corporate performance by mobilizing the company's resources and competences. It includes novel business operations or formulates novel approaches to current business operations which result into creating a different type of company. More 


\section{The International Journal}

ENTREPRENEURSHIP AND SUSTAINABILITY ISSUES

ISSN 2345-0282 (online) http://jssidoi.org/jesi/

2018 Volume 6 Number 2 (December)

http://doi.org/10.9770/jesi.2018.6.2(14)

and more managers believe that business model innovation will become more and more significant for corporate sustainability and development than product innovation.

Novel business models described as innovative business models (Laifi, 2012; Buchere, Eisert, Gassman, 2012). Since these business models relates to a novel system of operation (Amit, Zott, 2012) and innovative structures of creating and capturing value (Chesbrough, 2007) and alliances with partners and customer (Cortimiglia, Chezzi, Franck, 2016). Amit and Zott (2001) describe networks and alliances as basic frameworks for conception of innovative business models. Teece (2010) states that traditional business models focus merely on how to create, produce, sell a product and generate a profit from its production and sale. Novel business models resolve the same problems but in a innovative way which disrupt the seemingly undisputable business heurestics. Creating a novel business model in the widest sense does not necessarily means the development of a new product, change of processes or change of resources needed for production. The necessary effects are achievable though faster operations, customer solution provision, additional services provision, cooperation with communities, stimulating customer with pricing, breaking down barriers of access to products, new payment options or subscription, etc.

\subsection{Multiple value creation}

The notion of multiple value (Freeman, Wicks, Parmar, 2004) has been coined during sustainability reporting efforts (Marberg, Jonker, 2007). The theoretical framework of multiple value creation as a business foundation was formulated by McVea and Freeman in stakeholder theory (McVea, Freeman, 2005). The notion is based on the "triple bottom line" concept (Elkington, 1998). Thus, multiple customer value applies the principals of sustainable development. In this respect, assessing the choice of production technologies, production processes, and distribution channels, i.e. the business model, to promote eco-efficiency ensuring that the product/service exceeds customer expectations (Nidomolu, Prahalad, Rangaswami, 2009; Červený et al., 2013).

Multiple customer value is an incremental and differentiating part of the value proposition. It is manifested in business decision leading to the satisfaction of environmental and social expectations of both customers as well as the stakeholders partaking in the company's success. In this respect, partaking stakeholders aid the understanding of customer expectations. Sustainability in this sense underlines activities which can be repeated in the long run opposed to one-time actions. Sustainable multiple customer value, thus, supposes a long-term relationship emphasizing mainly customers and other stakeholders. The relationship is described by two trends which are heavily supported by technology (Le Vely, 2015). The first trend (push strategy) integrates sustainable multiple customer value creation in regard to market differentiation in developing and pushing products/services aiding the customer's eco-efficiency (water usage, energy storage, etc.). In the context of Industry 4.0 the exchange of information is reliant on information technologies. This sets the business model into a context described by its customer and stakeholders (the collected) and their expectations which will impact its business model configuration and thus its performance. On the other hand, a pull strategy aids the understating of customer expectations which leads to lowering opportunity costs. This relationship serves to contribute to the company's economic success, such as cost savings, competitiveness or sales increase, risk reduction, improved profitability, customer retention, reputation, etc. In conclusion the integration of sustainable multiple customer value creation into the business model presupposes that it is (Schaltegger, Lüdeke-Freund, Hansen, 2012):

- voluntarily with the intention to contribute to the solution of societal or environmental problems;

- creating a positive business effect or a positive economic contribution to corporate success which can be measured or argued for in a convincing way;

- clearly and convincingly argument that it lead to both, the intended or environmental effects, and the economic effect.

Novel business models in the context of sustainability is based on a marketing concept, i.e. the value proposition, leaning on positive environmental and social impacts in the core concept of the business model. Sustainable 
development offers space for the creation of a unique value proposition. It defines what the company can realize better than competitors and describes how the innovation serves the targeted market. It determines the customercentric focus leading to innovation, stimulating corporate flexibility. Innovating provided value is the first phase of reevaluting the business model (Dauchy, 2013). Conception of a unique value proposition enables concentration on the main aspects of multiple value creation for the target customer. This requires defining the target market, criteria of multiple value, proposition description (Chanal, 2011). The conception of a unique value proposition has to take into account the competitive space, since it is the customer's main argument why to engage and prefer a certain company over another when searching for a solution to meet their need.

In a novel business model the criteria of multiple value are founded in three dimensions comprised in the "triple bottom line" concept, i.e. environmental, social and economic value. It is expected that a novel business model based on sustainable multiple value creation will maximize and synergize all three dimensions.

\section{Methodology and research design}

The presented research is based on the stated theoretical background and presupposes that the dynamic of business model development forces companies to ponder the reasons and conditions of their existence. The business model Canvas is used as a visualization tool as it is sufficiently complex, analytical, flexible and general. Thus, suitable for research of novel business models aimed at multiple value creation in any industry. Frequency of occurrence of elements in the fields of the business model canvas enables the creation of a majority and minority business model construct (Slávik et al., 2014) which represents the basis of the research.

The majority business model construct. Competitors in a certain industry operate based on shared cognitive processes and achieve a consensus in suitable and viable strategies within the industry's context (Deephouse, 1999; Rhee, Kim, Han, 2006). The consesnsus is based on the narrow relations among the members in the competitive field. This, consequentially, influences the corporate vision and business model. This way, the cognitive consensus leads companies to ignore alternative business models over the dominant business model in the sector. Thus, a strategic change often comes from a subject from another sector which results in change of policy and competitive rules.

The majority business model aims to create a representation of a complete image of the prevalent business model, i.e. the majoritarian company comprising the most frequently used business model elements within the nine fields of the business model canvas. Hence, the majority business model is a referential model to identify trend changes and business model innovation. The majority business model possesses the most prevalent features in the industry and describe the mainstream of business model based on multiple value creation.

The minority business model represents the less frequently used elements in the industry. It is an array of experimental, little-used or fringe elements. It may possess rarely implemented but very perspective sustainable innovation in the industry. In general, the elements in the minority business model are still experimented with and are not standardized for widespread use, i.e. typical for certain companies.

Based on the theoretical background the following research questions were formulated:

[1] What type of customer do companies create multiple value in the industry for?

[2] Which elements are significant for the industry in terms of multiple customer value creation?

[3] Which elements compose novel business model design within the industry's context?

[4] How are minority business model elements distributed in the sample?

[5] How related are the business models in the industry? 
The International Journal

ENTREPRENEURSHIP AND SUSTAINABILITY ISSUES

ISSN 2345-0282 (online) http://jssidoi.org/jesi/

2018 Volume 6 Number 2 (December)

http://doi.org/10.9770/jesi.2018.6.2(14)

To answer these questions a methodology was developed to match the theoretical background and the specific context of the industry, CZ NACE 20.1 manufacture of basic chemicals, fertilizers, and plastics. The chemical industry is among the most capital-intensive ones where business model innovations are tied to technological improvements and incremental. The choice of the mentioned industry is due to its narrow context, i.e. companies within the industry share similar, they fall under the same regulation, and notably share the same business model framework. In this case, all companies manufacture basic chemicals, fertilizers, or plastics; share common stakeholders; and are influenced by European and national regulation.

Data collection methods include content analysis, semi-structured interviews and a survey. To answer the stated research questions. Other methods include Pearson's correlation coefficient (Slávik et al, 2014), and cluster analysis. To aid comprehension, data was visualized using tables, figures, and the visualization tool Business model canvas (Osterwalder, Pigneur, 2010).

The set of 52 elements provided in the work of Chen and Chiu (2015) served as the basis for the research. In the first phase, the exact elements were used during the content analysis of websites, reports, articles, etc. of all the companies within the sample. After reviewing the results, the set was reduced to 38 , due to no relevance to the industry's context.

Lastly, a questionnaire was developed to accommodate the 32 elements into 32 statements about the company to which respondents true or false. This is possible through the nature of business model elements, which represent a narrative of the company's activities. An activity is either present in the narrative or not. The survey was mainly aimed commercial or marketing directors, if not present in the company's structure, then production managers were contacted. All participants were contacted via phone for consent in participation in the survey and the questionnaire was sent via e-mail subsequently.

\subsection{Sample}

The sample consists of medium and large enterprises which belong into the CZ NACE group 20.1 manufacture of basic chemicals, fertilizers, and plastics. The companies were found using the database Amadeus and triaged based on the following criteria:

- active status;

- $\quad$ has headquarters or branch in the Czech republic;

- employee count greater than 75 employees;

- $\quad$ must belong to group 20.1 manufacture of basic chemicals, fertilizers, and plastics.

First results stated 49 companies in total, after reviewing, double entries and false entries were deleted leaving 42 companies. After, contacting each individual company during the distribution of the questionnaire commercial outlets and wholesalers were almost eliminated from the sample, leaving a final number of 38 companies. This sample of 38 companies is composed of 25 large and 13 medium-sized companies. Table 1 indicates the companies included in the research, their reference numbers, participation in the research, and business model structure. All of the 38 companies in the sample were contacted and 22 questionnaires were obtained, which represents a $57,89 \%$ response rate (Table 1$)$. 
The International Journal

ENTREPRENEURSHIP AND SUSTAINABILITY ISSUES

ISSN 2345-0282 (online) http://jssidoi.org/jesi/ 2018 Volume 6 Number 2 (December)

http://doi.org/10.9770/jesi.2018.6.2(14)

Table 1. Sample structure

\begin{tabular}{|c|c|c|c|c|c|c|}
\hline $\begin{array}{l}\text { Reference } \\
\text { number }\end{array}$ & Company name & $\begin{array}{l}\text { Company } \\
\text { size }\end{array}$ & $\begin{array}{l}\text { Participation } \\
\text { in research }\end{array}$ & $\begin{array}{c}\text { Number of } \\
\text { business model } \\
\text { elements }\end{array}$ & $\begin{array}{c}\text { Majority } \\
\text { business model } \\
\text { elements }\end{array}$ & $\begin{array}{c}\text { Minority } \\
\text { business model } \\
\text { elements }\end{array}$ \\
\hline 1 & Aerosol - service, a.s. & $\mathrm{L}$ & $\mathrm{X}$ & 18 & 13 & 5 \\
\hline 2 & Agra group, a.s. & $\mathrm{L}$ & $\mathrm{X}$ & 21 & 15 & 6 \\
\hline 3 & Agro cs, a.s. & $\mathrm{L}$ & $\mathrm{X}$ & 21 & 15 & 6 \\
\hline 4 & Akzo nobel coatings cz, a.s. & $\mathrm{L}$ & $\mathrm{X}$ & 17 & 13 & 4 \\
\hline 5 & Aroma praha, a.s. & $\mathrm{L}$ & $\mathrm{X}$ & 18 & 11 & 7 \\
\hline 6 & Bioferm - lihovar kolín, a.s. & $\mathrm{L}$ & & 2 & 2 & 0 \\
\hline 7 & Borsodchem mchz, s.r.o. & $\mathrm{M}$ & & 5 & 5 & 0 \\
\hline 8 & Contipro, a.s. & $\mathrm{L}$ & $\mathrm{X}$ & 32 & 16 & 16 \\
\hline 9 & Cs cabot, s.r.o. & $\mathrm{L}$ & $\mathrm{X}$ & 28 & 15 & 13 \\
\hline 10 & Deza, a.s. & $\mathrm{M}$ & $\mathrm{X}$ & 21 & 11 & 10 \\
\hline 11 & Ethanol energy, a.s. & $\mathrm{M}$ & $\mathrm{X}$ & 20 & 14 & 6 \\
\hline 12 & Farmak, a.s. & $\mathrm{M}$ & $\mathrm{X}$ & 20 & 14 & 6 \\
\hline 13 & Fosfa, a.s. & $\mathrm{M}$ & & 8 & 6 & 2 \\
\hline 14 & Global tungsten \& powders, s.r.o. & $\mathrm{L}$ & $\mathrm{X}$ & 20 & 15 & 5 \\
\hline 15 & Gs caltex czech, s.r.o. & $\mathrm{L}$ & $\mathrm{X}$ & 13 & 10 & 3 \\
\hline 16 & Ing. Petr Švec - penta, s.r.o. & $\mathrm{L}$ & $\mathrm{X}$ & 23 & 13 & 10 \\
\hline 17 & Jsp international, s.r.o. & $\mathrm{L}$ & & 4 & 4 & 0 \\
\hline 18 & Kordplast, s.r.o. & $\mathrm{L}$ & $\mathrm{X}$ & 14 & 9 & 5 \\
\hline 19 & Linde gas, a.s. & $\mathrm{M}$ & & 13 & 9 & 4 \\
\hline 20 & Linde vítkovice a. $\mathrm{S}$. & $\mathrm{L}$ & & 10 & 7 & 3 \\
\hline 21 & Lovochemie, a.s. & $\mathrm{M}$ & $\mathrm{X}$ & 15 & 11 & 4 \\
\hline 22 & $\begin{array}{l}\text { Lucební závody draslovka, a.s. } \\
\text { Kolín }\end{array}$ & $\mathrm{M}$ & $X$ & 26 & 14 & 12 \\
\hline 23 & Lučební závody, a.s. kolín & $\mathrm{L}$ & $\mathrm{X}$ & 26 & 14 & 12 \\
\hline 24 & Macco organiques, s.r.o. & $\mathrm{L}$ & $\mathrm{X}$ & 19 & 13 & 6 \\
\hline 25 & Mg odra gas, s.r.o. & $\mathrm{L}$ & $\mathrm{X}$ & 14 & 8 & 6 \\
\hline 26 & Norbrook, s.r.o. & $\mathrm{L}$ & & 2 & 2 & 0 \\
\hline 27 & Precheza, a.s. & $\mathrm{L}$ & $\mathrm{X}$ & 21 & 14 & 7 \\
\hline 28 & Proseat Mladá Boleslav, s.r.o. & $\mathrm{M}$ & & 4 & 3 & 1 \\
\hline 29 & Shadows - šedivec, s.r.o. & $\mathrm{L}$ & & 0 & 0 & 0 \\
\hline 30 & Siad czech, s.r.o. & $\mathrm{L}$ & $\mathrm{X}$ & 27 & 15 & 12 \\
\hline 31 & Silon, s.r.o. & $\mathrm{M}$ & & 6 & 3 & 3 \\
\hline 32 & Spolana, a.s. & $\mathrm{L}$ & & 3 & 3 & 0 \\
\hline 33 & $\begin{array}{l}\text { Spolek pro chemickou a hutní } \\
\text { výrobu, a.s. }\end{array}$ & M & & 15 & 12 & 3 \\
\hline 34 & Synthesia, a.s. & $\mathrm{L}$ & & 19 & 13 & 6 \\
\hline 35 & Synthon, s.r.o. & $\mathrm{L}$ & & 5 & 4 & 1 \\
\hline 36 & Synthos kralupy, a.s. & $\mathrm{M}$ & & 14 & 9 & 5 \\
\hline 37 & Unipetrol rpa, s.r.o. & $\mathrm{M}$ & & 18 & 14 & 4 \\
\hline 38 & Vodní sklo, a.s. & $\mathrm{L}$ & $\mathrm{X}$ & 21 & 14 & 7 \\
\hline
\end{tabular}

Source: Authors' own research

\section{Research results}

The following chapter states some of the findings of a larger research focused on describing novel business models based on sustainable multiple customer value creation. The research questions have been organized in a logical manner so that the answer to one question aids the answering of the following. The results provide an overview of the industry's business model structures and their characteristics in terms of sustainable multiple customer value creation. 


\subsection{What type of customer do companies create multiple value in the industry for?}

The first research question answers the need to identify for what kind of customer the industry creates, deliver, and capture value. Within the scope of the theoretical background, to what kind of customer do the companies in the industry gear their business models in order to meet their environmental and social expectations? Table 1 indicated the results, where the most prevalent customer for which companies create value for is a B2B customer $(70.22 \%)$.

Table 1. Sample structure

\begin{tabular}{|l|r|r|r|}
\hline Type of customer & Subsidiary & B2B customer & B2C customer \\
\hline Percentage & $17.56 \%$ & $70.22 \%$ & $12.22 \%$ \\
\hline \multicolumn{5}{|c}{ Source: Authors' own research }
\end{tabular}

\subsection{Which elements are significant for the industry in terms of multiple customer value creation?}

Two semi-structured interviews were further conducted to test the relevance on the remaining elements. The interviews were conducted with the production and commercial direction of Synthon, AS and the general director of the research and education center of Unipetrol, AS. Both interviews lasted around 60 minutes. In result, the set of elements was modified and reduced to 32, displayed in Table 2. The resulting elements had to be formulated in a wide enough sense to cover each company's specific context and narrow enough to portray the activity and its implications in the business model's narrative.

The elements in Table 2 were distributed according to the fields of the business model canvas for improved comprehension and visualization purposes. Table 2 also states the frequency of the elements in the sample which will is relevant to the following question.

Table 2. Significant business model elements in terms of multiple customer value creation

\begin{tabular}{|c|c|c|c|c|}
\hline $\begin{array}{l}\text { Business model } \\
\text { canvas field }\end{array}$ & Business model element & $\begin{array}{l}\text { Absolute } \\
\text { frequency }\end{array}$ & Frequency $(\%)$ & Minority model \\
\hline \multirow{6}{*}{ Value proposition } & Multiple product variants on offer & 32 & 84.21 & \\
\hline & Alternatives to products on offer & 17 & 44.74 & $\mathrm{X}$ \\
\hline & Environmentally friendly products & 24 & 63.16 & \\
\hline & Related products on offer & 16 & 42.11 & $\mathrm{X}$ \\
\hline & Individual planning & 23 & 60.53 & \\
\hline & Limiting use of dangerous substances in production & 23 & 60.53 & \\
\hline \multirow{4}{*}{ Key partners } & Suppliers of support services & 22 & 57.89 & \\
\hline & Local suppliers & 16 & 42.11 & $\mathrm{X}$ \\
\hline & Emphasis on industrial safety & 27 & 71.05 & \\
\hline & Cooperation with public and non-profit organizations & 11 & 28.95 & $\mathrm{X}$ \\
\hline \multirow{4}{*}{ Key activities } & B2B resource sharing & 4 & 10.53 & $\mathrm{X}$ \\
\hline & Commercial support for B2B customers & 21 & 55.26 & \\
\hline & Use of sustainable feedstocks & 18 & 47.37 & $\mathrm{X}$ \\
\hline & Use of energy saving equipment & 21 & 55.26 & \\
\hline \multirow{2}{*}{ Key resources } & Centralized waste treatment & 25 & 65.79 & \\
\hline & Take-back agreement & 10 & 26.32 & $\mathrm{X}$ \\
\hline \multirow{5}{*}{$\begin{array}{l}\text { Stakeholder } \\
\text { relations }\end{array}$} & Consulting & 27 & 71.05 & \\
\hline & Information and report sharing & 23 & 60.53 & $\mathrm{X}$ \\
\hline & Sharing experiences with customer and suppliers & 16 & 42.11 & $\mathrm{X}$ \\
\hline & Research cooperation & 18 & 47.37 & \\
\hline & Provision of internships & 20 & 52.63 & \\
\hline Channels & Online platform & 13 & 34.21 & $\mathrm{X}$ \\
\hline
\end{tabular}




\begin{tabular}{|c|c|c|c|c|}
\hline \multirow{5}{*}{ Cost structure } & Waste as an energy resource & 15 & 39.47 & $\mathrm{X}$ \\
\hline & Centralized waste treatment & 25 & 65.79 & \\
\hline & Waste recycling & 23 & 60.53 & \\
\hline & Financial support and sponsorships & 24 & 63.16 & \\
\hline & Education fund & 5 & 13.16 & $\mathrm{X}$ \\
\hline \multirow{5}{*}{ Revenue streams } & Rental of production facilities and equipment & 7 & 18.42 & $\mathrm{X}$ \\
\hline & Specialized services $(\mathrm{R} \& \mathrm{D})$ & 21 & 55.26 & \\
\hline & Full product-service solutions & 3 & 7.89 & $\mathrm{X}$ \\
\hline & Maintenance & 24 & 63.16 & $\mathrm{X}$ \\
\hline & Byproducts available as energy source or resource & 11 & 28.95 & $\mathrm{X}$ \\
\hline
\end{tabular}

\subsection{Which elements compose novel business model design within the industry's context?}

To answer this research, question the business models, the set of significant business model elements in Table 2 must be divided into two subsets. A subset which represents elements which are not novel in the context of the industry and a subset representing the novel elements. The research bases this division on the assumption that novel business model elements will be the ones less represented in the overall set of elements. Thus, the division in this case is based on an elements frequency (Table 2) and the subsets are represented as the majority business model and the minority business model. If the frequency of an element is greater that $51 \%$ it is attributed to the majority business model and vice versa.

The majority business model construct (Fig. 1) represents the most prevalent business model elements. Thus, a business model employed by most of companies in the industry and which would be needed to follow if a new competitor entered the market. In terms of a narrative approach (Margretta, 2011), the majority business model represents the general narrative of the industry.

Figure 1. Majority business model construct

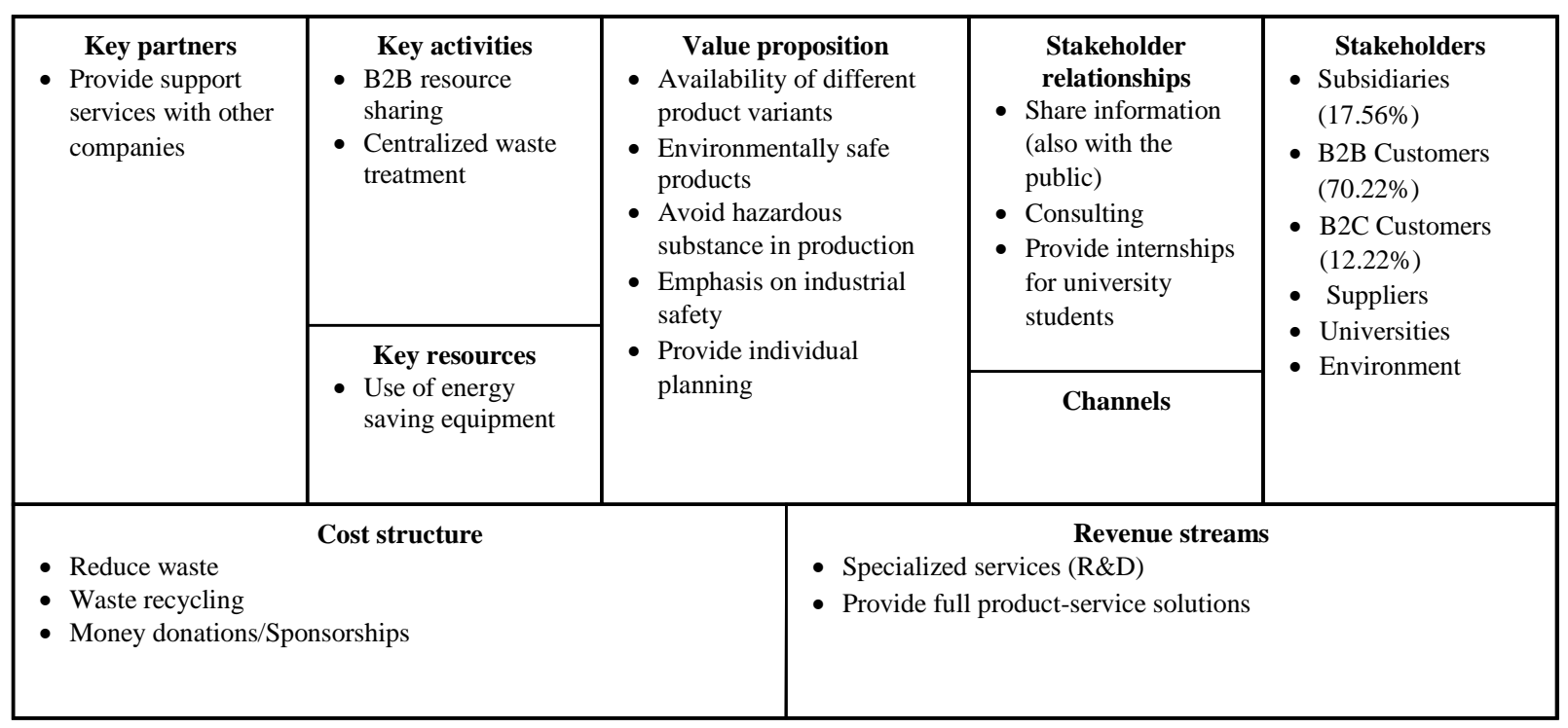

Source: Author's own research, modified according to Osterwalder et al., 2015

The minority business model construct (Fig. 2) represents, according to the definition of sustainable multiple value creation, a subset of differentiating elements which are geared towards satisfying the environmental and 
social expectations. The minority model construct displays the orientation towards a larger number of stakeholders, new income streams and opportunities to reduce opportunity costs and drive eco-efficiency. Notably, in the "channels" field where distribution is also ensured through an online platform connecting local suppliers and offering waste materials as a resource or energy source. It also shows greater openness to a larger number of stakeholders by sharing experiences with customer or suppliers, participating in academic research, and cooperation with public and non-profit organizations.

From the perspective of a narrative approach the minority model serves as a range of elements which modify the company's narrative business model. The construct, as it stands, cannot be applied to the whole industry due to its nature of being a collection of less frequently utilized elements. Companies are likely to utilize the full extent of elements of the majority model and only some from the minority model. Thus, minority model can serve as a tool to gauge whether a company engages in creating multiple customer value or not and follow the evolution of the industry through shifts of elements from and to the minority business construct.

Figure 2. Minority business model construct

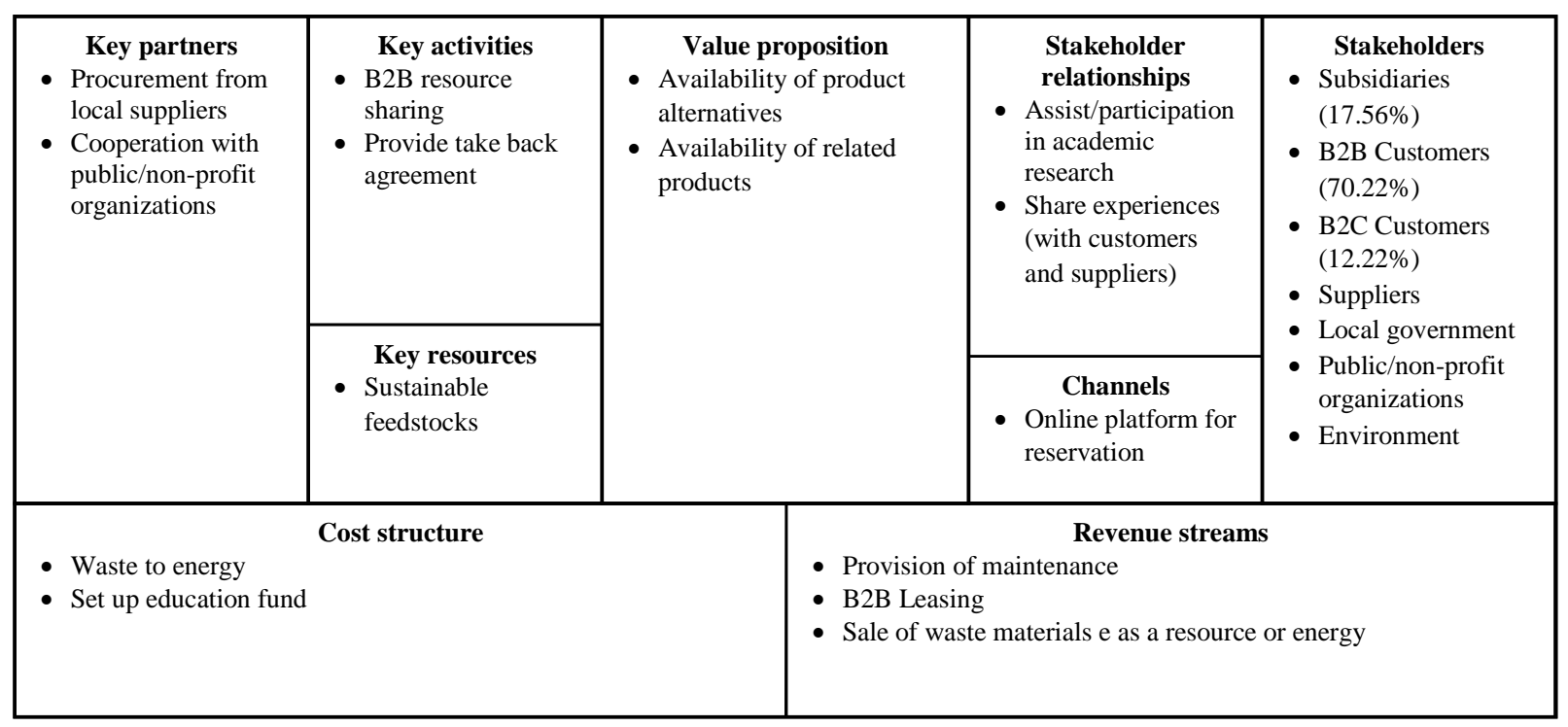

Source: Author's own research, modified according to Osterwalder et al., 2015

\subsection{How are minority business model elements distributed in the sample?}

Assuming that majority business model elements are present in every company's business model. The question aims at the distribution of minority business model elements (figure 3), whether they are distributed randomly throughout the industry's business models or are they concentrated.

To answer this question the range of companies according to the number of majority and minority business model elements (Table 1) were compared using Spearman's correlation coefficient. For the chosen significance level of $\alpha=0,05$ the resulting value of the coefficient is 0.813 , and the null hypothesis is rejected. Thus, there is a strong positive correlation between the range of companies according to the number of majority and minority business model elements. Hence, companies with a large number of majority business model elements in the business model also have a large number of minority business model elements. 


\subsection{How related are the business models in the industry?}

Cluster analysis of the industry's business models reveals that there are 3 major groups. The cluster dendrogram represents these groups (Figure 3). Companies are represented in figure 3 by their reference number from table 1. Cluster 1 is composed of 20 large-sized companies and 9 medium sized companies, for a total of 29. Cluster 2 is composed of 5 companies, all of which are large-sized. Finally, cluster 3 comprises 2 medium-sized companies and 2 large-sized companies. The structures of the clusters show that, although, companies are similar in terms of the business model their scale varies.

Figure 3. Results of Cluster analysis Cluster Dendrogram

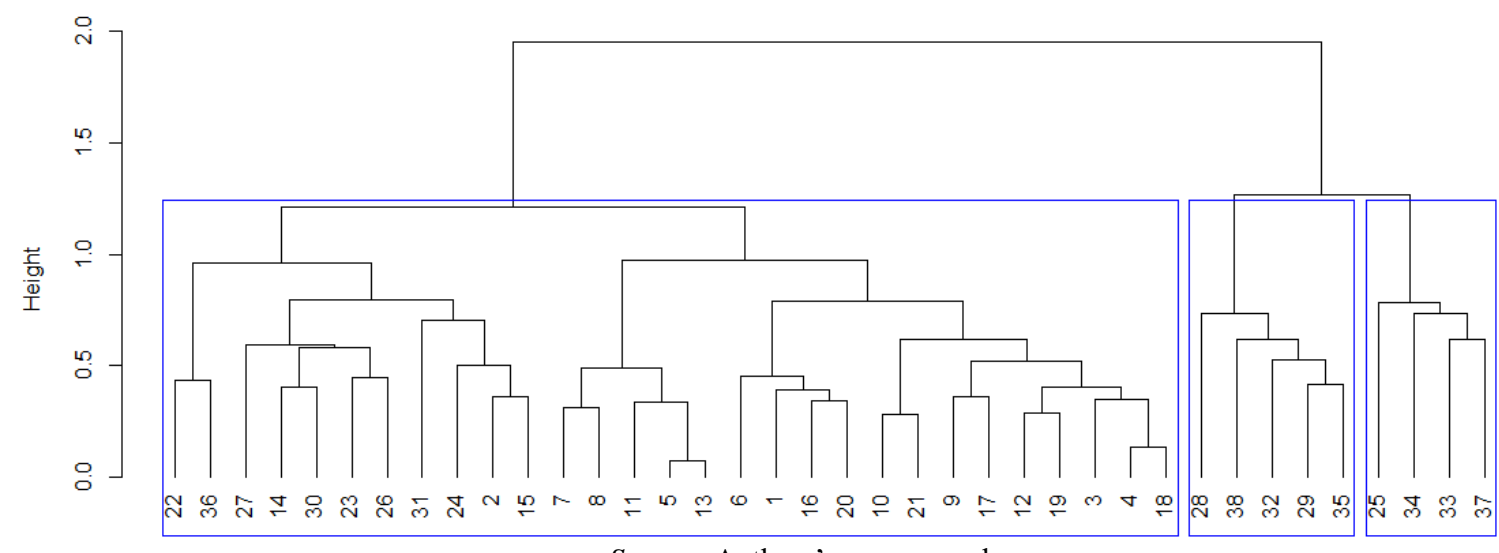

Source: Authors' own research

\section{Conclusions}

Business model research is often limited to case studies of one or a few companies. Few works have focused on studying an industry through the lens of its business models. Moreover, few works have studied the connection of specific business model elements and sustainability multiple value creation. Due to the narrow orientation of the research the results are very specific for these companies. Based on the minority business model construct, it is visible that the contained elements point to that novel business models shift to more of an open system through a service-based logic which aims to lower environmental impact. Although, the majority and minority constructs may seem similar in some terms, it is necessary to note that they represent narratives. The majority business model represents a meta narrative for the whole industry, whereas the minority model represents a collection of odd elements which fit into specific narratives of individuals companies and represent vast effort for implementation. Results portray the industry in terms specific business model elements connected to this theoretical construct. These elements served to formulate the industry's narrative in terms of sustainable multiple customer value creation. The narrative of the industry is as follows (figure 2):

The industry's prevalent narrative in terms of sustainable multiple customer value creation is as follows: Companies provide different product variants and individual planning solutions for their customers while emphasizing environmental safety of their products, industrial safety, and avoidance of hazardous substances in their production. This is achieved by providing support services to their customer with other companies, B2B resource sharing, centralized waste treatment, and usage of energy saving equipment. To provide this value proposition companies cooperate with their customers (subsidiaries 17,56 \%, B2B customers 70,22\%, B2C 
The International Journal

ENTREPRENEURSHIP AND SUSTAINABILITY ISSUES

ISSN 2345-0282 (online) http://jssidoi.org/jesi/

2018 Volume 6 Number 2 (December)

http://doi.org/10.9770/jesi.2018.6.2(14)

customers (12,22\%), suppliers, universities and taking the environment into consideration also as a stakeholder. Relationships with these stakeholders are upheld via sharing information about the company's functioning, providing consulting, and providing internships for university students. The cost structure includes promoting cost savings from reducing waste and recycling it, as well as carrying the costs of a fund for money donations and sponsorships. Revenue streams include providing specialized services like research and development and fullservice product solutions.

This narrative is modified by elements which serve as differentiating parts (figure 3). But, research showed that companies which employ a large number of majority business model elements also employ a large number of business model elements. Which could point at that the adoption of minority business model elements would be a function of scale, i.e., larger companies are able to differentiate more effectively due to having more resources available. But, cluster analysis showed that 2 out of 3 cluster were composed of companies of different size which support the claim that changing or adapting the business model is a significant non-technological innovation.

Future research involves the creation of specific concepts based on individual elements contained in the minority business model. These concepts can be acquired through statistical correlation of the existing data, to see exactly which elements correlate to specific elements. Other efforts will be focused on gaining access to specific performance data to pair it with the specific business models, thus providing evidence on how different configurations of elements in the business model affect social, environmental, and economic performance.

\section{References}

Amit, R.; Zott, C. 2012. C. Creating value through business model innovation. MIT Sloan Management Review Spring 2012,53 (3): $41-49$.

Amit, R.; Zott, C. 2001. Value Creation in E-Business. Strategic Management Journal 22 (6/7): 493-520. DOI: https://doi.org/10.1002/smj.187

Basl, J. 2002. Podnikové informační systémy: podnik vinformační společnosti. [Corporate information systems: the company in a information society ] Praha: Grada.

Beattie, V.; Smith, S. J. 2013. Value creation and business models: refocusing the intellectual capital debate. British Accouting Review 45 (4): 243-256. DOI: http://dx.doi.org/10.1016/j.bar.2013.06.001

Bocken, N. M. P.; Short, S. W.,; Rana, P.; Evans, S. 2014. A literature and practice review to develop sustainable business model archetypes, Journal of Cleaner Production 65: 42-56. DOI: http://dx.doi.org/10.1016/j.jclepro.2013.11.039

Boons, F.; Lüdeke-Freund, F. 2013. Business models for sustainable innovation: state-of-the-art and steps towards a research agenda. Journal of Cleaner Production 45 (14): 9-19. DOI: http://dx.doi.org/10.1016/j.jclepro.2012.07.007

Bucher, E.; Eisert, U.; Gassmann, O. 2012. Towards systematic business model innovation: lessons from product innovation management. Creativity and Innovation Management 21 (2): 183-198. DOI: https://doi.org/10.1111/j.1467-8691.2012.00637.x

Cortimiglia, M. N.; Ghezzi, A.; Frank, A. G. 2016. Business model innovation and stratégy making nexus evidence from a cross-industry mixed-methods study. $R \& D$ Management 46 (3): pp. 414-432. DOI: https://doi.org/10.1111/radm.12113

Červený, R.; Hanzelková, A; Keřkovský, M. \& P. Němeček 2013. Strategie nákupu: krok za krokem. [Purchasing strategy: step by step] Praha: C.H.Beck.

Dalíková, D. 2013. Spoločenská odpovědnost podniku a vytváření sdílené hodnoty. [Corporate social responsibility and shared value creation] The scientific conference INPROFORUM. České Budějovice: Jihočeská univerzita, 47-52. 
Dauchy, D. 2013. 7 étapes pour un business model solide. [7 steps to a solid business mode] Paris: Dunod.

Deephouse, D. 1999. To be different or to be the same? It's a question (and theory) of strategic balance. Strategic Management Journal 20 (2): 147-172. DOI: https://doi.org/10.1002/(SICI)1097-0266(199902)20:2<147::AID-SMJ11>3.0.CO;2-Q

Elkington, J. 1998. Partnerships from cannibals with forks: The triple bottom line of 21 st-century business [Online]. Environmental Quality Management 8(1): 37-51. DOI: http://doi.org/10.1002/tqem.3310080106

Freeman, R.; Wicks, A.; Parmar, B. 2004. Stakeholder Theory and "The Corporate Objective Revisited" [Online]. Organization Science, 15(3): 364-369. DOI: https://doi.org/10.1287/orsc.1040.0066

Girotra, K., Netessine, S. 2013. OM - forum - business model innovation for sustainability. Manufacturing \& Service Operations Management, 14(4): 537-544. DOI: $\underline{10.1287 / \mathrm{msom} .2013 .0451}$

Chabi, S. 2016. Le développement durable dans l'entreprise: un question de marketing. [Sustainable development in a company: a question of marketing] Revue Française du Marketing 257: 73-87. Available on the Internet: https://www.association-etienne-thil.com/wpcontent/uploads/2018/01/2010-25MorinDelerm_Charriere.pdf

Chanal, V. 2011. Business models dans l'innovation. [Business models in innovation] Grenoble: PUG.

Chen, Y. T.; Chiu, M. C. 2015. A case-based method for service-oriented value chain and sustainable network design. Advanced Engineering Informatics 29(3): 269-294. DOI: https://doi.org/10.1016/j.aei.2015.06.005

Chesbrough. H. 2007. Business model innovation: It's not just about technology anymore. Strategy \& Leadership 35(6): 12-17. DOI: https://doi.org/10.1108/10878570710833714

Chwaszcz, O. 2010. Inovace obchodního modelu. [ Business model innovation] Ekonómia a podnikanie 4(1): 45-57.

Jakubíková, D. 2008. Strategický marketing. [ Strategic marketing] Praha: Grada.

Jensen, A. 2013. Do we need one business model definition? Journal of Business Models 1(1): 61-84. DOI: https://doi.org/10.5278/ojs.jbm.v1i1.705

Kašparová, K. 2006. Společenská zodpovědnost podniku - způsoby jejího měření a vztah k finanční výkonnosti podniku. [Corporate social responsibility - ways of measurement and relation to financial performance] In Vývojové tendence podniků II. - Svazek I. Brno: Masarykova univerzita.

Kocmanová, A.; Šimberová, I. 2014. Determination of environmental, social and corporate governance indicators:framework in the measurement of sustainable performance. Journal of business economics and management, 15: 1017-1033. DOI: https://doi.org/10.3846/16111699.2013.791637

Koráb, V.; Mihalisko, M. Založení a řizeni společnosti. [Founding and managing a business] Brno: Computer Press.

Kunz, V. 2012. Společenská odpovědnost firem. [Corporate social responsibility] Praha: Grada Publishing.

Laifi, A. 2012. De la légitimité d'un business model innovant. Cas de la bibliothèque numérique Cyberlibris. [Legitimacy of a innovative business mnodel. Case study of electronic library Cyberlibris] Revue française de gestion 38(223): 75-89. DOI: 10.3166/rfg.223.77-89

Lankauskienè, T; Tvaronavičienè, M. 2012. The Impact of Production Factors and Economic Structures on Economic Development. Journal of Security \& Sustainability Issues Jun2012, 1(4), 287-297. DOI: https://doi.org/10.9770/jssi.2012.1.4(5)

Lehman-Ortega, L.; Misikas, H.; Schoetti, J. M. 2017. Ré-inventer votre business model. [Re-invent your business model] Paris: Dunod.

Leon, F. 2014-15. La construction des business models des fournisseurs d'infrastructure as-a-service: l'étude de deux „purs players“ français. [Construction of business models of infrastructure providers: case study of two French ,pure players] Gredeg working paper. Sophia Antipolis: Univercité Nice, 29 p. [online]. [2017-03-04]. Available from the Internet: www.gredeg.cnrs.fr/workingpapers/GREDEG-WP-2014-15.pdf 
Le Vely, D. 2015. L'industrie chimique en France: quel avenir? [The chemical industry in France: what does the future hold?] Annales des Mines - Réalités industrielles, mai 2015, (2): 20-23. Available on the Internet: https://www.cairn.info/revue-realites-industrielles-2015-2page-20.htm.

Livre Vert: l'esprit d'entreprise en Europe. [The Green Book:The spirit of business in Europe] Bruxelles:COM, 2003: 27 [cit. $2014-03-$ 08], [online] Available from the Internet: http://www.insme.org/files/107.

Liikanen, E. 2004. Entrepreneuriat responsable. [Responsible enterpreneurship] Bruxelles: Commission européenne.

Marberg, A.; Jonker, J. 2007. CSR and multiple value cration: a social movement in the making? Revue de l'organisation Responsable 2(3): 5-17.

Mcvea, J.; Freeman, R. 2005. A Names-and-Faces approach to stakeholder management: how focusing on stakeholders as individuals can bring ethics and entrepreneurial strategy together. Journal of Management Inquiry 14(1): 57-69. Available form the Internet: https://doi.org/10.1177/1056492604270799

Muehlhausen, J. 2018. Modele biznesowe dla bystraków. [Business models for dummies] Gliwice: Helion.

Nidumolu, R.; Prahalad, C.; Rangaswami, M. 2000. Why sustainability is now the key driver of innovation. Harvard Business Review 87(9): 56-64. Available from the Internet: https://hbr.org/2009/09/why-sustainability-is-now-the-key-driver-of-innovation

Osterwalder, A.; PIGNEUR, Y. 2010. Business Model Generation. John Wiley and Sons.

Pavlík, M.; Bělčík, M. et al. 2010. Společenská odpovědnost organizace - CSR v praxi a jak s ním dál. [Corporate social responsibility CSR in practice and what to do with it] Praha: Grada Publishing, a.s.,

Pilný, I. 2016. Digitální ekonomika: žit anebo přežit. [The digital economy: thrive or survivre] Brno: Bizbooks.

Prskavcová, M.; Maršíková, K.; Řehoříková, P.; Zbanková, M. 2008. Společenská odpovědnost firem, lidský kapitál, rovné př́ležitosti a environmentální management s vyuţitím zahraničnich zkušeností. [Corporate social responsibility, human capital, equal opportunities and environmental management using foreign expertise] Liberec: TU.

Rhee, M.; Kim, Y.; Han, J. 2006. Confidence in Imitation: Niche-Width Strategy in the UK Automobile Industry. Management Science 52(4): 501-514.

Schaltegger, S.; Lüdeke-Freund, F.; Hansen, E. G. 2012. Business cases for sustainability: the role of business model innovation for corporate sustainability. International Journal of Innovation and Sustainable Development 6(2): 95-119. [online]. [2018-3-4]. Available from the Internet: https://ssrn.com/abstract=2010510.

Schaltegger, S.; Hansen, E. G.; Lüdeke-Freund, F. 2016. Business models for sustainability: origins, present research, and future avenues. Organization \& Environment 29(3): 3-10. DOI: https://doi.org/10.1177/1086026615599806

Slávik, Š. et al. 2014. Podnikatel’ské modely. [Business models] Bratislava: Vydavatel'stvo EKONÓM.

Slávik, Š., Bednár, R., Ljudvigová, I., Mišún, J., Procházková, K., Vogl, M., et al. 2014a. Stratégie a podnikatel’ské modely v postindustriálnej ére podnikania II. [Strategy and business models in the postindustrial era of entrepreneurship II.] Bratislava: EKONÓM.

Słavinska, M. 2010. Modele biznesu w handu detalicznym. [Business models in retail] Poznan: WUE.

Švejda, P. 2002. Základy inovačního podnikání. [Basics of innovative busine] Praha: Asociace inovačního podnikání ČR.

Teece, D. J. 2010. Business models, business strategy and innovation. Long Range Planning 43(2-3): 172-194. DOI: https://doi.org/10.1016/j.1rp.2009.07.003

Tvaronavičienè, M. 2018. Towards sustainable and secure development: energy efficiency peculiarities in transport sector. Journal of Security and Sustainability Issues 7(4): 719-725. DOI: $\underline{\text { https://doi.org/10.9770/jssi.2018.7.4(9) }}$ 
Zädražilová, D. et al. 2010. Společenská odpovědnost podniků. Transparentnost a etika podnikání. [Corporate social responsiblity. Transparency and business ethics] Praha: C.H.Beck.

Zadražilová, D. 2011. Udržitelné podnikání. [Sustainable business] Praha: Oeconomica.

Záležáková, E. 2014. Podnikatel’ský model a zodpovedné podnikanie. [The business model and responsible business] In Slávik, Š. 2014a Stratégie a podnikatel'ské modely v postindustrálnej ére II. Bratislava: EKONÓM.

\section{Aknowledgements}

This paper was supported by the research project: Use of the holistic concept in company management, which is founded by Specific Research of FBM BUT, grant number FP-J-18-4915.

Peter KITA is a. PhD student at the Faculty of Business and management of Brno University of Technology in the Czech Republic. Dissertation treats the topic of novel business models based on sustianable multiple customer value creation. Research interests: business models, business modelling for sustainable value creation, and novel business models design.

ORCID ID: orcid.org/0000-0002-6508-9056

Iveta ŠIMBEROVÁ is associate professor and also the vice-dean for international relations of the Faculty of Business and Management at Brno University of Technology in the Czech Republic. Her main research areas are: sustainability, business models: innovations and dynamism. Her publication list involved more than 20 original articles in scientific reviewed journals, 6 specialized books (co-author of specified chapters, 67 articles in reviewed conference proceedings).

ORCID ID: orcid.org/0000-0002-9236-4439

Copyright (C) 2018 by author(s) and VsI Entrepreneurship and Sustainability Center This work is licensed under the Creative Commons Attribution International License (CC BY). http://creativecommons.org/licenses/by/4.0/

c) (7) Open Access

